\title{
TEORI KEBENARAAN DALAM PEMIKIRAN HUKUM AL-GHAZALY (1058-1111 M): Kajian Filosofis-Metodologis
}

\author{
Ahmad Rofiq \\ Universitas Islam Negeri (UIN) Walisongo Semarang Jawa Tengah \\ E-mail:ahmadrofiqabrar@gmail.com
}

\begin{abstract}
According to Al-Ghazaly, truth must be seen and placed within the framework of belief and certainty, ranging from the form of indrawy, khayaly, to beliefs that will not be influenced by any factor. Therefore, he clarifies man in the category of lay and khawas. This is so that someone does not necessarily make generalizations and make sure that someone has made a mistake. This paper will examine in fact what the theory of truth is in the thought of Al-Ghazaly's law and how it is constructed epistemologically. The goal is to know about the theory of truth and how the methodology it developed. The study finds that according to Al-Ghazaly, the truth in legal thought, must be seen and placed within the framework of belief and certainty. The confirmed truth of religion or al-ma'lum min al-din bi-durahurah requires one to accept it with submission.
\end{abstract}

Keywords: Al-Ghazaly; Law Thought; Theory of Truth

\begin{abstract}
ABSTRAK
Menurut Al-Ghazaly, kebenaran harus dilihat dan diletakkan dalam kerangka keyakinan dan kepastian, mulai dari wujud indrawy, wujud khayaly, hingga keyakinan yang tidak akan dapat dipengaruhi oleh faktor apapun. Karena itu pula, ia mengklafisikan manusia pada katagori awam dan khawas. Ini dimaksudkan agar seseorang tidak merta melakukan generalisasi dan memastikan bahwa seseorang telah melakukan kesalahan. Tulisan ini akan mengkaji sesungguhnya apa teori kebenaran dalam pemikiran hukum Al-Ghazaly dan bagaimana teori tersebut dibangun secara epistemologis. Tujuannya, untuk megetahui tentang
\end{abstract}


teori kebenaran dan bagaimana metodologi yang dikembangkannya tersebut. Penelitian ini menemukan, bahwa menurut Al-Ghazaly, kebenaran dalam pemikiran hukum, harus dilihat dan diletakkan dalam kerangka keyakinan dan kepastian. Kebenaran yang telah dipastikan dari agama atau al-ma'lum min al-din bi-dlarurah menuntut seseorang wajib menerimanya dengan ketundukan.

Kata Kunci: Al-Ghazaly; Pemikiran Hukum; Teori Kebenaran.

\section{A. Pendahuluan}

Al-Ghazaly lahir di Thus (Khurasan) tahun 1058, adalah seroang tokoh fenomenal di masanya. Hingga kini kebesaran namanya sangat dikagumi banyak orang, baik di Barat maupun di Timur. Ia dikenal sebagai ahli hukum (faqih), teolog (mutakallim), filosof, dan sufi sekaligus. Nama lengkapnya Abu Hamid Muhammad bin Muhammad bin Muhammad Al-Ghazaly. Hafalannya terhadap hadits tidak kurang dari 100.000 hadits mengantarkan dirinya diberi gelar Hujjatul Islam (Argumentasi Islam).

Pendidikannya diawali dengan berguru kepada Radzkani, lalu pindah ke Jurjan untuk berguru kepada Abu al-Qasim al-Isma’ily. Ilmu yang ia tekuni pertama adalah ilmu fiqh atau yurisprudensi (Fakhry, 1986:304). Tahun 1077 M, dalam usia 19 tahun, ia pindah ke Nishapur untuk berguru kepada Imam al-Juwainy (1028-1085 M). Gurunya inilah yang memperkenalkan Al-Ghazaly ke dalam dunia teologi (Watt, 1990:260), filsafat dan logika (Fakhry, 1986:305). Ia juga belajar sufisme kepada alFarmadzi (w. $1084 \mathrm{M})$, seorang sufi terkemuka waktu itu.

Sepeninggal gurunya, Al-Juwainy, ia dimintabergabung di Madrasah Nidhamiyah yang didirikan oleh Nadham al-Muluk, wazir (menteri) Sultan Seljuk Maliksyah. Al-Ghazaly menjabat sebagai guru besar pada usia 33 tahun. Setelah itu, Al-Ghazaly mengalami "krisis batin" atau semacam kegalauan intelektual, mengalami kesulitan bicara yang menghambatnya dalam memberikan kuliah. Akibat krisis tersebut, ia mengembara ke Baghdad, Damaskus, dan Jerusalem. Setelah itu menunaikan ibadah haji. Setelah pengembaraannya ini, ia kembali ke Thus, untuk menjalani kehidupan baru yang sarat dengan semangat dan nuansa sufistik.

Dalam karya autobiografisnya, menurut Fakhry (h. 305), sebanding dengan Confessions-nya St. Agustinus, Al-Ghazaly menceritkan ihwal kecemasan dan keraguan spiritual dan intelektualnya yang dramatis, 
pengunduran dirinya di puncak kemasyhurannya, dan karier intelektualnya sebagai guru di Baghdad (1095 M). Ia diliputi perasaan kecemasan atau "krisis batin" seperti suatu penyakit yang sungguh-sungguh diderita selama hampir dua bulan. Akhirnya, ia mendapatkan kesehatan intelektualnya pulih kembali, setelah mendapatkan suatu pengalaman melalui seberkas "cahaya" yang Tuhan masukkan ke dalam hatinya yang sesungguhnya, yang merupakan kunci bagi hampir semua jenis pengetahuan” (AlGhazaly, t.th.:13). Menurut versi Montgomery Watt (261), Al-Ghazaly bersikap skeptic dan bertekad untuk mencari kebenaran (religious) sejati dalam empat tempat yang paling mungkin didapati kebenaran itu, yaitu: di kalangan teolog-reasional, para filosuf, kaum Bathiny (Isma'ily), dan di kalangan sufi (mistis).

Banyak karya telah ditulis Al-Ghazaly, namun Al-Mushtasfa min 'Ilm al-Ushul, oleh Ibrahim Sulaiman, disebut sebagai karya momumental terbaik madzhab Sunny, yang belum banyak dikaji, di samping Al-Burhan fi Ushul al-Fiqh karya Imam al-Haramain al-Juwainy. Boleh jadi ini karena yang menonjol dan dikenal masyarakat. Dalam pemikiran hukum Islam, utamanya dalam fiqh dan ushul fiqh, Al-Ghazaly berafiliasi kepada madzhab Syafi'I, meskipun dalam menulis Al-Mustashfa, menurut AlMaraghy (237), ia banyak merefer kepada Kitab al-Mu'tamad karya Abu al-Husain al-Bashry (w. $436 \mathrm{H} / 1044 \mathrm{M}$ ).

Jika hipotesis Al-Maraghy tersebut benar, besar kemungkinan AlGhazaly lebih cenderung menggunakan pendekatan rasional ( $\left.r a^{\prime} y u\right)$ dalam mengelaborasi pemikiran hukumnya. Ini didukung bahwa Al-Ghazaly juga seorang filosuf, yang "menyerang" pemikiran filsafat dan menerima logika sebagai instrumen dan metode pengembangan intelektualnya.

Dalam formuasi hukum Islam, di luar teks nash Al-Qur'an dan al-Sunnah, dikenal term ijtihad (metode formulasi hukum). Ijtihad merupakan proses kerja intelektual seseorang yang memiliki kualifikasi sebagai mujtahid, untuk mengambil atau derivasi - baik terhadap lahiriyah teks atau menangkap ruh tasyri'nya - suatu nash, ia memiliki risiko kebenaran dan kesalahan dari ijtihadnya itu. Ini dapat ditangkap dari petunjuk eksplisit sebuah hadits riwayat dari 'Amr bin al-Ash bahwa Nabi saw bersabda: "Apabila seorang hakim berijtihad, dan (ternyata) benar, 
maka baginya dua pahala. Dan apabila ia berijtihad, dan (ternyata) salah, maka ia mendapat satu pahala” (Muttafaq 'alaih).

Apabila ijtihad kemudian dilihat dalam konteks dinamika dan pembaharuan hukum Islam, hadits riwayat Abu Dawud menyatakan bahwa Rasulullah saw mengatakan: "Sesungguhnya Allah mengutus pada setiap penghujung 100 tahun, seseorang yang memperbaharui (pemahaman) agamanya” (Riwayat Abu Dawud). Hadits tersebut secara eksplisit menegaskan akan pentingnya pemikir pembaharu pada setiap seratus tahun untuk memformulasikan pemahaman agama. Soal apakah hasil itjtihad atau pemikiran pembaharuannya benar (al-shawab) atau salah (al$\left.k h a t h a^{\prime}\right)$, memiliki peluang yang sama, meskipun akan lebih berat terjatuh pada pilihan benar.

Dalam khazanah fiqh, dengan ilmu alatnya ushul fiqh, fiqh sebagai produk kerja intelektual serang faqih atau juris, meskipun sama-sama mengambil dari nash yang saa, hasilnya bisa berbeda atau beragam, dan karena itu kebenarannya bersifat relatif (nisby). Pertanyaan filosofisnya adalah, mana di antara kebenaran-kebenaran formulasi hasil kerja intelektual tadi yang memiliki muatan kebenaran hakiki, karena sesungguhnya kebenaran secara logika hanyalah satu. Jika teori ini benar, maka implikasinya dapat dikatakan, bahwa jika hasil ijtihad seorang ulama mujtahid adalah benar, maka ijtihad ulama lainnya salah. Hasil ijtihad ulama yang benar itulah yang mendapat dua pahala, tetapi anehnya yang hasil ijtihadnya salah, tetap mendapat satu pahala.

Atas dasar pemikiran tersebut, kranya menarik untuk diteliti apa dan bagaimana teori kebenaran menurut Al-Ghazaly dan bagaimana implikasinya terhadap pemikiran hukum Islamnya.

\section{B. Pembahasan}

\section{Al-Ghazaly Selayang Pandang.}

Al-Ghazaly lahir di Thus Khurrasan tahun 405 H/1058 M, dan wafat tahun $505 \mathrm{H} / 1111 \mathrm{M}$ di kota yang sama. Nama lengkapnya Abu Hamid Muhammad bin Ahmad al-Ghazaly. Al-Ghazaly kecil harus merelakan diri menjadi yatim di usia sangat muda, karena ditinggal wafat 
orang tuanya. Karena itulah, ia tumbuh mandiri dan penuh percaya diri (al-Ghazaly, Al-Munqidz, t.th:21).

Sapaan laqab-nya Hujjatul Islam ini, karena hafalannya terhadap ratusan ribu hadits, kadang disebut juga dengan Zain al-Din al-Thusy. Nama kunyah-nya Abu Hamid. Al-Ghazaly adalah seorang ahli hukum Islam, faqih, yang berafiliasi kepada madzhab Syafi'i, ahli ushul fiqh, sufi, penyair dan sastrawan, dan pengasuh para pengembara intelektual ke jalan yang lurus. Ia disebut juga sebagai tokoh yang berhasil menggabungkan ilmu-ilmu naqly dan 'aqly sekaligus (al-Maraghy, II:8).

Orang tuanya seorang faqir yang shalih. Pekerjaannya memintal benang wool (bulu domba) dan menjualnya di toko di kawasan Thus. Lebih dari itu, ia tidak mengonsumsi makanan kecuali dari hasil kerja tangannya sendiri. Ia senang duduk bergabung bersama para fuqaha' dan melayani mereka. ketika ia mendengar nasihat para faqih tersebut, ia menangis dan merendahkan hati dan dirinya (tadharru') kepada Allah seraya menangis dan memohon agar dikaruniai anak yang faqih dan pemberi nasihat.

Doa Ahmad ternyata dikabulkan oleh Allah, dan dikaruniai dua orang anak, yakni Ahmad dan Muhammad. Ahmad kelak menjadi penasehat yang lemah lembut, sementara Muhammad juga menjadi ahli fiqh terkemuka di Persi pada zamannya. Lengkaplah, Al-Ghazaly dan saudaranya menjadi tokoh penting yang dicatat sejarah dan menjadi orang yang banyak member manfaat kepada lingkungannya yang terpancar dari ilmu pengetahuan dan kealimannya.

Keharuman nama Al-Ghazaly juga masih terasa hingga sekarang, termasuk di Indonesia. Karya monumentalnya Ihya' 'Ulumiddin merupakan salah satu karya yang banyak dikaji di pesantren dan majlismajlis halawah para Ulama. Bahkan pengalaman batin dan sufistiknya menjadi rujukan bagi penembara sufistik di hamper seluruh dunia Islam.

Konsep ma'rifat yang menjadi tahapan penting dalam tasawuf, menokohkan dirinya dalam jajaran tokoh sufi yang diklasifikasikan ke dalam tasawuf sunny, melalui pengalaman kasyf-nya yakni tersingkapnya ilmu-ilmu rububiyah (ketuhanan) yang dapat membuka tabir ke-ghaib-an.

Pengembaraan inelektual Al-Ghazaly sangat panjang. Karena itu, ia tidak lama tinggal di negerinya sendiri. Setelah berguru dengan Ahmad 
bin Muhammad al-Razkany tentang fiqh, ia pindah ke Jurjan untuk belajar kepada Abi Nashr al-Isma'ily. Di sini ia sempat membuat Ta'liqat (catatan anotasi) dari gurunya. Setelah itu ia kembali ke Thus untuk menekuninya lebih dalam selama tiga tahun hingga hafal catatan ta'liqat-nya itu.

Setelah itu, Al-Ghazaly memilih Nisabur untukmenemui dan belajar kepada Imam al-Haramain Abu al-Ma'aly al-Juwainy. Ia berguru dengan Al-Juwainy hingga wafat $(477 \mathrm{H} / 1080 \mathrm{M})$. Saat itu, nama AlGhazaly namanya mulai dikenal luas, mengembara ke Irak. Al-Ghazaly bertemu dengan menteri Nizam al-Muuk dan menyampaikan persoalan pentingnya pengajaran di sekolah Nizamiyah di Baghdad, $484 \mathrm{M}$.

Al-Ghazaly tercatata sebagai anak muda yang rajin dan tekun, sampai akhirnya ia menguasai ilmu fiqh, khilafiyah, perdebatan (jadal), ushuluddin, ushul al-fiqh, hikmah dan filsafat. Kemampuan intelektualnya ini kemudian dituangkan dalam tu;isan dengan menulis beberapa kitab. Kadang ia juga mengritik gurunya. Selain itu, ia termasuk sangat cerdas, pandangannya maju, kemampuannya mengagumkan, kuat hafalannya, dan segala macam sifat terpuji lainnya. Malahan, Imam al-Haramain menyebutkan: "Al-Ghazaly adalah lautan yang dalam" atau "bahrun 'amiq) (Ibid., h. 9). Suatu ungkapan tulus dan memuji yang tidak mengada-ada.

Setelah itu, didirikanlah madrasah dan Al-Ghazaly diminta ikut mengajar di situ selama empat tahun, hingga akhirnya terkena "serangan penyakit" yang memaksanya harus meninggalkan Irak. Montgomery Watt (261) menyebutkan, Al-Ghazaly bersikap skeptis dan bertekad mencari kebenaran (religious) sejati dalam empat tempat yang paling mungkin didapati kebenaran itu, yakni: di kalangan teolog-rasional, para filosuf, kaum Batiny (Isma'ily), dan di kalangan sufy (mistis). Dari Irak ia menuju Hijaz untuk menunaikan ibadah haji, setelah itu ke Syam dan bermukim di al-Quds kurang lebih dua tahun.

Dari al-Quds, Al-Ghazaly melanjutkan perjalanan menuju Iskandariyah Mesir. Dari Mesir inilah, Al-Ghazaly kembali ke kampus lama Al-Nizamiyah. Setelah itu, Fakhr al-Mulk bin Nadhdham menetapkannya sebagai guru di Madrasah Nishabur. Ketika Imam al-Haramain wafat, AlGhazaly dari Nishabur melanglang buana ke Mu'askar untuk menemui wazir Nizham al-Mulk. Di sini, rumahnya menjadi tempat berkumpul para ilmuwan dan sastrawan. Kehadiran Al-Ghazaly disambut secara antusiaqs, 
karena tutur kata Al-Ghazaly yang lembut, fasih bicaranya, bagus integritas moral-pribadinya, dan menyenangkan hati banyak orang di sekelilingnya.

Di Mu'askar ini, Al-Ghazaly sudah memulai kehidupan zuhudnya, awal kegiatan sufistiknya. Tahun $488 \mathrm{H}$, Al-Ghazaly menunaikan ibadah haji dan menunjuk saudaranya menjadi asisten untuk menggantikan tugas mengajarnya. Sekembalinya dari Mekah, Al-Ghazaly menuju Syam dan mukim di kota Damaskus, dan mengisi kesibukan hariannya dengan mengembangkan ilmu di zawiyah masid Jami. Setelah itu ia menuju ke Baitul Maqdis, lebih bersungguh-sungguh dalam beribadah, dan untuk sementara mengisolasi diri dari lingkungannya untuk menekuni ibadahnya di tempat-tempat yang sepi dari keramaian. Pengalaman inilah yang kemudian dikenal dengan 'uzlah (mengasingkan diri).

Dari Baitul Maqdis, Al-Ghazaly meneruskan pengembaraan intelektualnya menuju Mesir dan bermukim di Iskandari beberapa saat. Dari sini, Al-Ghazaly bermaksud melanjutkan pengembaraan ke Negaranegara Maghriby untuk menemui Gubernur Yusuf bin Tasyfin, penguasa Maroko. Namun sesampainya di Maroko, ia tidak dapat memenuhi keinginannya, maka is kembali ke Thus untuk menghabiskan waktunya menekuni karir keilmuanya, beribadah, dan mengarang beberapa kitab. Sejak itu sampai dengan wafatnya, Al-Ghazaly tidak lama memiliki kesempatan untuk menurunkan ilmunya kepada murid-muridnya. Di Thus inilah, Allah memanggilnya, tahun $505 \mathrm{H} / 1111 \mathrm{M}$, dan dimakamkan di Thaberan (Ibid., h.22).

Al-Ghazaly memiliki banyak keahlian dalam berbagai disiplin ilmu, dari fiqh dan ushul fiqhm filsafat, kalam (teologi), hingga tasawuf. Karya tulisnya banyak, tidak kurang dari 200-an dan yang sudah diterbitkan sekitar 50-an. Dalam bidang fiqh, Al-Ghaaly menlis: al-Basith, al-Wasith, dan al-Wajiz. Dalam ushul fiqh, ada al-Mustashfa, al-Mankhul, al-Maknun, dan Syifa' al-Ghalil. Dalam filsafat, dikenal ada Tahafut al-Falasifah, alHikmah fi Makhluqat Allah, Tanzih al-Qur'an al-Mathain, Jawahir al-Qur'an wa Duraruh, Risalah al-Thair, Bidayah al-Hidayah, Tahdzib al-Nufus bi alAdab al-Syar'iyyah, dan al-Qisthas al-Mustaqim.

Dalam ilmu kalam atau teologi, Al-Ghazaly menulis: al-Iqtishad fi al-I'tiqad, al-Arba'in fi Ushul al-Din, Iljam al-'Awam, al-Imla' 'an Isykalat al-Ihya', dan Faishal al-Tafriqah baina al-Islam wa al-Zindiqah. Dalam ilmu 
tasawuf dan sebagian dengan pendekatan fiqh, Al-Ghazaly menulis: Ihya' 'Ulumiddin, Asrar al-Hajj, Iljam al-Awam, al-Imla' 'an Isykalat al-Ihya', alRisalah al-Ladunniyyah, al-Risalah al-Qudsiyah, dan yang berkaitan dengan etika politik alTibr al-Masbuq fi Nashihat al-Muluk.

Akan halnya tentang kebesaran Al-Ghazaly, Noercholish Madjid (1984:33) mengatakan dengan lugas, bahwa Al-Ghazaly diakui sebagai salah seorang pemikir paling hebat dan paling orisinal, tidak saja dalam Islam tetapi juga dalam sejarah intelektual manusia (1984:33). Di mata banyak sarjana modern Muslim maupun non-Muslim. Al-Ghazaly adalah orang terpenting sesudah Nabi Muhammad saw, ditinjau dari segi pengaruh dan peranannya dalam menata dan mengukuhkan ajaranajaran keagamaan.

Montgomery (1987:138) menambahkan "Al-Ghazaly telah diakui baik oleh orang-orang Islam maupun sarjana-sarjana Eropa, sebagai muslim trbesar sesudah Muhammad. Apakah mereka jujur atau tidak, ini soal yang pelik. Yang jelas, Al-Ghazaly dipandang sebagai seorang penuis teologi yang menyenangkan dan paling mudah difahami”.

Kritik yang cerdas bisa dilakukan Al-Ghazaly, karena ia menguasai filsafat al-Faraby dan Ibnu Sina dengan jalan belajar sendiri. Suatu prestasi yang belum pernah dicapai oleh teolog manapun saat itu. Selain itu, AlGhazaly juga menguasai seni itu secara mendalam. Ia membuat kritiknya yang kompeten, tidak dipersoalkan lagi. Ini karena ia menggunakan metode filsafat itu sendiri yang ia pinjam dari terutama Ibnu Sina.

Karyanya Tahafut al-Falasifah (Kerancuan Filsafat) yang diterjemahkan ke dalam bahasa Inggris The Inconsistency of The Philosophers, karena terdorong oleh gejala berkecamuknya pikiran bebas waktu itu yang membuat banyak orang meninggalkan ibadah (Madjid, 1984:34). AlGhazaly yang menggabungkan antara filsafat dan teologi (kalam) melihat bahwa ilmu kalam memiliki keterbatasan. Karena itu, agama harus didekati dengan menggunakan kehidupan zuhud sufistik untuk mendekatkan diri pribadi kepada Tuhan.

Harun Nasution (1989:41) mengatakan, bahwa perasaan syak (ragu-ragu) terhadap segala sesuatu, timbul dari pelajaran ilmu kalam (teologi) yang diperolehnya dari Al-Juwainy. Karena di dalam teologi 
terdapat beberapa aliran pemikiran yang saling bertentangan. Timbullah dalam diri Al-Ghazaly pertanyaan "aliran manakah yang benar di antara semua aliran itu?

Ini mirip dengan pengalaman al-Asy'ary yang mula-mula ditolak dan dicurigai umat, terulang pada Al-Ghazaly. Meskipun ia sepenuhpenuhnya membela agama, tetapi pembelaan itu dilakukan denan memperkenalkan berbagai cara berfikir dan metode yang saat itu dirasakan sebagai heterodoks dan bid'ah, maka wajar mendapat penentangan, dan dianggap sebagai menyalahi tradisi pemikiran keagamaan. Namun berkat pemikiran Al-Ghazaly itulah, maka Asy'arisme mendapatkan kemenangannya yang terakhir, yang kelak menjadi cirri utama faham sunny. Dari sinilah, kesenjangan antara sufisme dan bidang-bidang agama lainnya, semakin menciut. Akhirnya, Al-Ghazaly berhasil member tempat yang mapan pada esoterisme Islam dalam keseluruhan faham keagamaan yang dianggap sah atau ortodoks (Madjid, 1984:35).

Philip K Hitti (1973:432) menempatkan tawaran Al-Ghazaly sebagai pemikiran yang begitu hebat, dan memukau dunia intelektual Islam dan membuat seolah terbius tak sadarkan diri. Implikasinya, ia dianggap telah membangun sebuah kamar bagi umat Islam, walaupun sangat nyaman, namun berefek memenjarakan kreatifitas intelektual Islam yang konon sampai sekarang (Madjid, 1984: 35). Sejak itu, masih menurut Noercholish Madjid, umat Islam tidak akan mendapatkan kembali dinamika intelektualnya jika tidak berhasil memecahkan kamar sel Ghazalisme itu.

Terlepas dari "tuduhan" seperti tersebut di atas, Al-Ghazaly amat berjasa dalam menstabilkan pemahaman umat kepada agamanya. Karena berbagai kekacauan umat dalam pemahaman agama mereka, teratasi. Dan stabilitas inilah yang mengesankan seolah melahirkan terjadinya kemandegan dan keterpenjaraan intelektual.

Intensitas Al-Ghazaly belajar tasawuf sudah dimulai sejak masih muda. Sepeninggal ayahnya, bersama saudaranya ia diasuh oleh teman orang tuanya, semasa masih di Nishabur, yakni seorang ahli hukum namun pemimpin sufi di situ, Al-Farmadhi (w. 1084 M). Ini yang disebut oleh Watt (1987:144) sebagai awal menjalin keakraban dengan faham sufi baik dalam teori maupun praktik, dan setelah itu beralih ke filsafat dan teologi. 
Oleh sebagian penerusnya, Al-Ghazaly memasuki tasawuf karena peraturan pelaksanaan yang tertera dalam syariah di ditinggalkan. Tetapi anggapan demikian, tidak benar, karena Al-Ghazaly justru mengarahkan bahwa permulaan praktik sufi yang sesungguhnya terletak pada kepatuhan yang mentap dalam menjalankan kewajiban-kewajiban syariah itu. Hanya atas landasan yang demikian itulah, seeorang dapat mencapai situasi kebatinan yang lebih tinggi yang merupakan wilayah khusus sufisme. Dari situasi batin inilah, Al-Ghazaly dapat menulis berdasarkan pada pengalaman pribadinya. Ini yang kemudian tidak dapat diktakan bid'ah, tetapi sebagai kombinasi antara kepatuhan dalam pelaksanaan syariah dengan pendekatan sufistik.

Syeikh Zainuddin al-Malibary yang menegaskan, bahwa "menjalankan syariah (fiqh) tanpa hakikat adalah kosong tak berisi, menempuh hakikat tanpa syariat (fiqh) adalah batal”. Al-Ghazaly lebih tegas lagi menyatakan : "man tafaqqaha wa lam yatashawwaf faqad tafassaqa, wa man tashawwafa wa lam yatafaqqah faqad tazandaqa, wa man tafaqqaha wa tashawwafa faqad tahaqqaqa" artinya "barang siapa berfiqh (saja) tidak bertasawwuf, sungguh ia fasiq, barang siapa yag bertasawwuf dan tidak berfiqh, sungguh ia zindiq, dan barang siapa berfiqh dan bertasawwuf, sungguh ia adalah berhakikat (benar) (Al-Ghazaly, 4:tt).

Illustrasi tersebut menunjukkan bahwa tidak pada tempatnya, menimpakan tanggung jawab kemunduran intelektualisme dunia Islam kepada Al-Ghazaly. Buktinya, sepeninggalnya, di Spanyol, muncul seorang ulama yang berkemampuan intelektual luar biasa, yang berusaha memecahkan sel Ghazalisme. Dialah Ibn Rusyd, Abu alWalid bin Muhammad bin Ahmad bin Rusyd (w. 595 H/1198 M) yang dikenal sebagai ahli fiqh dan ahli fisafat Aristoteles terbesar dan terakhir dalam Islam.

Karerna itu pula, menelusuri pemikiran Al-Ghazaly dalam bidang fiqh dan metodologi emikirannya, terutama tentang teori kebenaran, menjadi menarik. Terlebih pemikiran metodologi telah dibukukan dalam tiga karya besar beliau, Al-Mustashfa, AL-Mankhul, dan Syifa' al-Ghalil. 


\section{Filsafat dan Kebenaran Agama.}

Filsafat berasal dari bahasa latin philo dan shopia artinya cinta kebijaksanaan. Dalam bahasa Arab lebih dikenal dengan falsafah (فلسفة) atau sering disebut juga dengan hikmah (حكمة) atau wisdom. Ibnu Rusyd (w. $594 \mathrm{H} / 1198 \mathrm{M}$ ) menulis buku yang berisi tentang pembelaannya terhadap filsafat kaitannya dengan syariat dengan judul Fashl al-Maqal fima baina al-Hikmah wa al-Syariah min al-Ittishal artinya "Rincian Pembicaraan Hubungan antara Filsafat dan Syariah".

Secara terminologis, filsafat menurut al-Kindi, adalah ilmu pengetahuan mengenai sebab dan realitas Ilahi yang pertama dan merupakan sebab dari semua realitas lainnya. Karena itu pula Al-Kindi melukiskannya sebagai ilmu dari segala ilmu dan kearifan dari segala kearifan (Syarif, 1985:12). Dalam redaksi yang lain, filsafat didefinisikan sebagai ilmu pengetahuan tentang hakikat segala sesuatu dalam batasbatas kemampuan manusia (Atiyeh, 1983:6). Karena itu, menurut AlKndi, filsafat dan agama tidak bertentangan dan bahkan selaras dan saling mendukung. Keselarasan ini didasarkan pada tiga alasan, pertama, ilmu agama merupakan bagian dari filsafat; kedua, wahyu yang diturunkan kepada Nabi dan kebenaran filsafat saling bersesuaian; dan ketiga, menuntut ilmu secara logika diperintakan dalam agama (Syarif, 1985:17).

Bagi Al-Ghazaly, kebenaran yang meyakinkan dirinya hingga tidak terpatahkan oleh argumentasi apapun, lebih diutamakan. Kutipan panjang dari Montgomery Watt menggambarkannya:

"Pertama-tama, yang kucari adalah ilmu tentang hakikat segala sesuatu, maka jelas aku harus berusaha mengetahui hakikat ilmu. Sudah jelas bagiku, bahwa pengetahuan yang pasti sepasti-pastinya adalah pengetahuan tentang obyeknya terungkap dengan cara yang begitu rupa sehingga tidak ada lagi kesangsian yang melekat padanya, sehingga tidak ada lagi kekeliruan atau ilusi yang menyertainya, dan akal tidak dapat lagi mengandaikan adanya kemungkinan itu. Pengetahuan yang pasti juga harus tidak dapat dipersoalkan; dan kepastian ini atau jaminan terhadap kekeiruan adalah begitu rupa sehingga usaha yang bagaimana pun untuk menunjukkan kepalsuan pengetahuan itu tidak akan dapat menimbulkan kesangsian atau sanggahan, sekalipun dilakukan oleh seseorang yang dapat mengubah batu menjadi emas, atau sebuah tongkat menjadi ular". Demikianlah aku tahu bahwa sepuluh lebih besar dari pada tiga. Andaikata seseorang berkata kepadaku: "Tidak, tiga itu lebih besar daripada sepuluh, dan sebagai buktinya aku akan mengubah tongkat itu menjadi ular". Dan seandainya ia benar-benar mengubah tongkat menjadi ular, dan aku 
menyaksikan dia berbuat demikian, maka tidak akan timbul dalam diriku kesangsian tentang apa yang aku tahu karena hal itu. Satu-satunya akibat adalah bahwa aku akan merasa terheran-heran tentang bagaimana cara yang sebenarnya sehingga ia mampu melakukan perubahan itu. Tentang pengetahuanku, sedikit pun tidak timbul kesangsian” (1952: 21-22).

Untuk mencapai tujuan yang lebih tinggi di dalam mencari kebenaran mutlak, Al-Ghazaly melakukan penyelidikan tentang filsafat. Ia mempelajari filsafat Yunani dengan tekun dan memperoleh keahlian yang tinggi. Dari penjelajahan intelektualnya selama tiga tahun, ia menulis Maqashid al-Falasifah yang diterjemahkan ke dalam bahasa Latin tahun $1145 \mathrm{M}$ oleh Dominicus Gundissalinus dengan judul Logica et Philosophia Al-Gazalis Arabis.

Buku tersebut, oleh Al-Ghazaly dimaksudkan untuk menjelaskan ajaran-ajaran para filosuf, sebagai persiapan untuk menolak pandangan mereka dalam sebuah karya berikutnya (Al-Ghazaly, t.t., 31-33, 385). Kemudian muncul anggapan, bahwa Al-Ghazaly adalah seorang Neo-Platonis sejati sebagaimana Ibn SIna dan yang lainnya. Padahal sesungguhnya, tujuan Al-Ghazaly yang utama bukanlah mengembangkan melainkan menyanggahnya. Majid Fakhry (1986:311) mengatakan, sumbangan utama Al-Ghazaly sebenarnya terletak pada pemihakannya kepada kelompok anti-filsafat dan usahanya untuk membuktikan kerancuan para filosuf dan dassar-dasar filsafat mereka. di sinilah kepentingan AlGhazaly dalam sejarah pemikiran filsafat dalam Islam. Bagi Al-Ghazaly, pengetahuan yang diperoleh secara langsung dari Tuhan dengan melalui tasawwuf itulah satu-satunya jalan pengetahuan yang menimbulkan keyakinan akan kebenarannya.

Al-Ghazaly ketika menulis Tahafut al-Falasifah lebih bersifat keagamaan. Ia melihat sudah ada sekelompok kecil pemikir bebas terdorong untuk menanggalkan keyakinan-keyakinan Islam dan mengabaikan dasardasar pemujaan ritual dengan menganggapnya sebagai tidak berguna bagi pencapaian intelektual mereka. ini diperburuk lagi, oleh adanya pujian berlebihan kepada para filosuf kuno, dari Sokrates hingga Aristoteles, yang secara keliru dipandang telah mengambil bagian dalam ketidak beragamaan meeka. Padahal, kata Majid Fakhry (1986: 311), setiap orang terkemuka di antara orang-orang kuno dan modern, menganut dua asas keberagamaan, yaitu eksistensi Tuhan dan realitas hari kiamat (Al-Ghazaly, t.t,: 6). 
Al-Ghazaly memandang para filosuf sebagai pembuat bid'ah (ahl al-bida') yang tergolong pembuat kesesatan. Ada dua puluh masalah filsafat yang dianggapnya salah, dan ditulis dalam Tahafut al-Falasifah. Namun dari dua puluh masalah tersebut, menurut Harun Nasution (1985:44) dapat diringkas menjadi sepuluh masalah. Majid Fakhry, mengatakan bahwa enam belas menyangkut masalah metafisika, dan empat soal fisika yang berkaitan erat dengan soal agama, dan terhadap mana seorang yang beriman yang lengah, harus diperingatkan.

Selain itu, ada tiga masalah yang menjijikkan dilihat dari sudut pandang agama, dank arena itu orang-orang yang membenarkannya harus dinyatakan murtad, yaitu tentang: keabadian dunia, pengetahuan Tuhan hanya atas hal-hal yang universal, dan penolakan terhadap kebangkitan jasmani (Al-Ghazaly, Tahafut: 376, al-Munqidl, 23-24). Sementara tujuh belas lainnya tidak menyebabkan penganutnya menjadi kafir, tetapi tergolong bid'ah.

Dalam pandangan Harun Nasution (1985: 44) sepuluh masalah pokok yang dianggap menyebabkan murtad, adalah:

1. Tuhan tidak mempunyai sifat;

2. Tuhan memounyai substansi (basith) sederhana dan tidak mempunyai hakikat (mahiyah).

3. Tuhan tidak mengetahui hal-hal rinci (juz'iyyat).

4. Tuhan tidak dapat diberi sifat jenis (al-jins).

5. Planet-planet adalah bintang yang bergerak dengan kemauan.

6. Jiwa-jiwa planet mengetahui semua juz'iyat.

7. Hukum alam tidak dapat berubah.

8. Pembangkitan jasmani tidak ada.

9. Alam tidak bermula.

10. Alam ini kekal.

Adapun tiga dari sepuluh proposisi tersebut menurut Al-Ghazaly menyebabkan penganutnya masuk ke dalam kekufuran, yaitu:

1. Alam ini kekal dalam arti tidak bermula.

2. Tuhan tidak mengetahui perincian dari apa-apa yang terjadi di ala mini.

3. Pembangkitan jasmani tidak ada. 
Tentang keabadian dunia, seperti dianut kaum Neo-Platonis Islam dan Aristoteles (Fakhry, 1986:312). Pada umumnya para filosuf berpendapat bahwa alam ini adalah qadim. Artinya, wujud ala mini bersamaan wujudnya Tuhan. Teori ini disebut dengan teori emanasi atau pemancaran (al-faidl al-Ilahy). Sejak Tuhan ada, sejakitu pula Tuhan disebut dengan al-Khaliq, Yang Maha Pencipta. Dengan sendirinya, sejak itu pula alam menjadi ada sebagai ciptaannya. Dipandang dari segi waktu, wujud Tuhan dan wujud alam adalah bersamaan, meskipun secara tingkatan dzat-Nya, Tuhan lebih dahulu dari pada alam, sebagaimana sebab mendahului akibatnya atau angka satu mendahului dari angka dua (Hanafi, 1981: 17).

Alasan berikutnya yang dikemukakan filosuf, adalah bahwa sesuatu yang baru mustahil keuar dari yang qadim. Sekiranya alam yang baru itu dapat keluar dari yang qadim dan diselangi waktu, tentu diperlukan alasan lagi yang kuat mengapa alam itu baru timbul kemudian, tidak sebelumnya. Persoalan pokoknya adalah, terletak pada waktu timbulnya alasan untuk mengadakan alam (Ibid., 18). Al-Ghazaly dalam Tahafut al-Falasifah (h. 29030) menbatakan, bahwa pandangan filosuf terhadap massalah keabadian alam, dinyatakan menjadi tiga: pertama, pandangan mayoritas yang luas, kuno, maupun modern, yang mempercayainya sebagai abadi. Kedua, pandangan Plato yang mempertanyakan bahwa dunia diciptakan dalam waktu, dan ketiga, pandangan Galen yang menunda persoalan ini. Jadi, sebelum alam ada, Tuhan belum mau menciptakannya, dan ketika Tuhan sudah mau menciptakannya, barulah alam ini ada.

Alasan tersebut juga menimbulkan pertanyaan. Pertama, kemauan itu timbul dari Tuhan sendiri? Ini mustahil, sebab dzat Tuhan tidak dapat mengalami perubahan dari belum menjadi mau. Kedua, kemauan itu tidak timbul dari dzat Tuhan. Hal ini berarti bahwa bukan Tuhan yang mempunyai kemauan untuk mencipta (Hanafi, 1981: 19). Al-Ghazaly mengajukan argumentasi untuk menyanggah kaum eternalis ini, bahwa dunia diciptakan dalam waktu. Karena itu bertentangan dengan konsep Al-Qur'an tentang konsep penciptaan ex-nihilo, yang sebagai konsekuensi logisnya mengikutsertakan suatu pembahasan yang sewenang-wenang terhadap kekuasaan mutlak Tuhan. Dalam kaitan ini, Al-Ghazaly menolak tuntutan bahwa selang waktu yang memisahkan keputusan abadi Tuan 
dengan penciptaan dunia memasukkan anggapan bahwa Tuhan tidak dapat menyelesaikan penciptaan itu sekaligus. Tuntutan ini tidak bersandar pada dasar-dasar demonstratif melainkan semata-mata merupakan suatu pernyataan dogmatis, Al-Ghazaly, Tahafut, h. 29-30).

Lebih dari itu, Al-Ghazaly mengajukan alas an, pertama, bahwa ala mini diciptakan Tuhan dengan iradah-Nya yang qadim. Wujud ala mini dikehendaki Tuhan ketika ia wujud dan ketiadaan wujud sebelumnya karena Tuhan belum menghendakinya. Dan ketika Tuhan menghendaki wujudnya alam dengan iradah-Nya yang qadim, maka alam pun terwujud. Apa yang tidak memungkinkan diterimanya pendapat ini? Kedua, dalam ala mini terdapat banyak yang mempunyai sebab. Jika yang baru itu bersumber dari yang baru pula, terjadilah rentetan berkesudahan. Hal ini adalah mustahil serta tidak dapat diterima akal. Seandainya semua yang baru itu mempunyai ujung penghabisan atau berkesudahan, maka ujung itulah yang qadim. Karena itu, tidak dapat tidak, haruslah diterima keluarnya yang baru dari Tuhan yang qadim.

Dengan argumentasi tersebut, Al-Ghazaly ingin menegaskan, bahwa terjadinya alam setelah ia pernah tidak ada, tidak mengandung arti perubahan dzat Tuhan. Iradah Tuhan untuk menciptakan alam bersifat qadim. Dengan kata lain, iradah Tuhan menciptakan alam sejak azali, dan iradah itu tidak berubah-ubah sampai tiba saatnya ala mini tercipta dalam kenyataan. Selain itu, tidaklah mustahil yang baru keluar dari yang qadim.

Tampaknya, di sini terdapat perbedaan persepsi. Al-Ghazaly memahami alam syahadah yang kasat mata, sementara para filosuf memahaminya sebagai alam materi asal (al-hayula al-ula) yang memancar dari Tuhan tanpa melalui proses waktu. Karena itu, Al-Faraby mengatakan, "alam terjadi dengan tidak mempunyai permulaan dalam waktu, yaitu tidak terjadi secara berangsur-angsur, tetapi sekaligus dengan tak berwaktu" (Nasution, 1989:28).

Proposisi kedua yang dipandang dapat menyebabkan kufur seeorang adalah tentang pengetahuan Tuhan tentang hal yang rinci (juz'iyyat). Alasan mereka, pertama, Juz'iyyat berdasarkan waktu, seperti terjadinya gerhana matahari melalui tiga keadaan, yaitu (1). Ada suatu keadaan ketika gerhana belum ada, tetapi wujudnya ditunggu, yaitu seseorang akan menunggu bahwa "gerhana akan terjadi"; (2). Pada keadaan 
kedua gerhana benar-benar ada, seseorang akan berkata "gerhana sedang terjadi”; dan (3). Ketika gerhana itu tidak ada atau sudah selesai, seseorang akan berkata "gerhana telah terjadi". Dengan kata lain, pengetahuan mengikuti obyek pengetahuan. Apabila obyek pengetahuan berubah, maka pengetahuan pun ikut berubah. Apabla pengetahuan berubah, maka orang yang mengetahui harus merubah pengetahuannya. Perubahan semacam ini, mustahil bagi Tuhan.

Kedua, Tuhan mengetahui juz'iyyat secara menyeluruh (kully). Para filosuf mengakui bahwa Tuhan mengetahui gerhana dan segenap sifat-sifatnya, tetapi Tuhan mengetahui dengan ilmu-Nya yang bersifat azali dan kully yang tidak berubah-ubah. Pengetahuan tentang hal itu berdasarkan hukum sebab akibat, tanpa terikat dengan waktu tertentu. AlGhazaly mengemukakan bantahannya dengan merujuk pada pemikiran Al-Asy'ary tentang pengetahuan Tuhan. Tindakan kehendak (iradah) menyatakan secara tidak langsung pengetahuan dari apa yang dikehendaki, dank arena seluruh dunia telah dikehendaki Tuhan, maka akibatnya dunia secara keseluruhan diketahui-Nya dan ditimbulkan oleh tindakan ganda pengetahuan dan kehendak ini (Al-Ghazaly, Tahafut., h. 210-211). Bagi Al-Ghazaly, agar Tuhan dapat mengetahui dan berkehendak maka berarti Ia harus hidup, dan sudah semestinya Ia mampu mengetahui segala sesuatu yang memancar dari-Nya bersama-sama dengan diri-Nya sendiri sebagai sumbernya.

Kaum Neo-Platonis, kata Majid Fakhry (1986:317) yang telah menelanjangi Tuhan dari semua sifat-sifat yang essensial, berkesimpulan, bahwa "Tuan dari segala Tuan dan Sebab dari segala Sebab tidak mampunyai pengertian apapun tentang sesuatu yang terjadi di dunia ini”. Pokok argument Ibn Sina dalam hal ini misalnya adalah, bahwa Yang Pertama sebagai yang sama sekali immaterial, haruslah merupakan sebuah intelek murni ('aql) dank arena itu harus mengetahui segala sesuatu karena satu-satunya penghalang bagi pengetahuan seperti itu adalah materi (AlGhazaly, Tahafyt, h. 211).

Al-Ghazaly kukuh pada pendiriannya, karena mengutip Al-Qur'an (Surat Saba', 24:2) yang menegaskan bahwa apa saja yang terjadi dialam ini Allah mengetahuinya. Firman Allah : 'ya'lamu ma yaliju fi al-ardli wa ma yakhruju minha wa ma yanzilu min al-sama'i wa ma ya'ruju fiha wa huwa al- 
rahim al-ghafur" artinya "Dia mengetahui apa yang masuk ke dalam bumi, apa yang keluar dari padanya, apa yang turun dari langit dan apa yang naik kepadanya. Dan Dialah Yang Maha Penyayang lagi Maha Pengampun”.

Ayat tersebut menegaskan bahwa tidak ada satu pun yang luput dari pengetahuan Tuhan. Termasuk di dalamnya juga partikel terkecil di langit dan di bumi. Namun terhadap bantahan ini, para filosuf tetap membantah. Ibn Sina menegaskan, bahwa Tuhan mengetahui segala sesuatu selain diri-Nya, tetapi modus pengetahuan-Nya bersifat universal. Menurutnya, pengetajuan universal tidaklah tunduk seperti "pengetahuan particular" kepada pembatasan-pembatasan ruang dan waktu. Bagi Al-Ghazaly, pengetahuan Tuhan benar-benar bebas dari persyaratanpersyaratan ruang dan waktu. Dengan pertimbangan itu, pengetahuan ini tidaklah mengecualikan hal-hal yang particular, yang tunduk kepada persyaratan-persyaratan seperti itu. Perubahan yang mungkin terjadi pada modus pengetahuan ini tidaklah mengikutsertakan perubahan esensi yang mengetahui, melainkan hubungan pengetahuannya dengan obyek yang terus menerus berubah (Fakhry, 1986: 319).

Ketiga, adalah tentang pembangkitan jasmani. Para filosuf mengatakan, bahwa setelah kematian, tubuh jiwa mengekal selamalamanya baik dalam keadaan senang yang tidak mungkin terlukiskan karena begitu besarnya, atau dalam keadaan sengsara yang tak mungkin terlukiskan karena begitu besarnya. Kadang-kadang kesengsaraan itu menjadi abadi dan kadang-kadang menghilang bersama perjalanan waktu. Tingkatan-tingkatan kesengsaraan manusia berkelompok-kelompok tak terhitung banyaknya, sebagaimana mereka berbeda-beda dalam tingkatan-tingkatan duniawi dan kesenangannya dengan perbedaan yang tak terhitung banyaknya (Al-Yazijy, 1963: 229). Tingkatan-tingkatan jiwa mereka bagi kepada tiga, yakni: (1). Kesenangan yang abadi adalah jiwa yang suci dan sempurna; (2). Kesengsaraan yang abadi adalah untuk jiwajiwa yang tidak sempurna dan kotor; (3). Kesenangan yang sementara adalah untuk jiwa-jiwa yang kotor tetapi sempurna. Adapun jiwa-jiwa yang dapat mencapai kebahagiaan mutlak adalah jiwa yang dapat mencapai kesempurnaan (kamal), kesucian (tazkiyah), atau kebersihan (thaharah). Kesempurnaan diperoleh dari pengetahuan dan kesucian dihasilkan dari perbuatan yang baik. 
Mereka menambahkan alasan penolakan mereka, apabila jasmani itu akan dibangkitkan maka aka nada tiga kemungkinan yang terjadi, yaitu: (1). Jasmani yang sudah menjadi tanah itu bangkit di akhirat dengan kehidupan baru, bukan kelanjutan kehidupan di dunia. (2). Jiwa manusia tetap ada sesudah mati, kemudian dikembalikan jasmaninya yang pertama, lengkap dengan anggota tubuh seperti sediakala. (3). Jiwa akan hidup kembai dengan menempati badan, apakah badan itu yang semula atau badan baru yang lain.

Mereka mengemukakan, alasan pertama tidak mungkin terjadi. Karena hal itu bukan kebangkitan namanya. Kebangkitan adalah kembalinya sesuatu yang pernah hidup, kemudian dihidupkan kembali sesudah matinya sebagai kelanjutan kehidupan yang pertama. Alasan kedua mustahil terjadi, karena badan manusia telah hancur bersama dengan tanah sesudah mati. Sebagian tubuh telah diserap oleh bakteri-bakteri, tumbuhtumbuhan, dan berpindah-pindah ke tubuh hewan pemakan tanaman dan daging tidak mustahil beralih ke dalam tubuh manusia lainnya yang memakan tumbuh-tumbuhan dan hewan-hewan itu. Alassan ketiga juga mustahil terjadi. Karena hal ini menyebabkan perpindahan roh dari jasmani yang satu ke jasmani yang lain. Perpindahan jiwa seperti ini akan menimbulkan kekacauan dan sulit diterima akal.

Untuk mematahkan argumentasi mereka yang menurut Al-Ghazaly (Tahafut, h. 354) memang tidak meyakinkan, satu-satunya jalan adalah menggunakan otoritas Kitab Suci atau wahyu. Al-Qur'an menegaskan bahwa ada keabadian dengan cara yang meyakinkan dalam kehidupan setelah mati di akhirat. Al-Ghazaly menyatakan,

"Apa yang kami permasalahkan adalah bahwa pengetahuan mereka tentang keabadian jiwa dan kesenangan-kesenangan atau penderitaan-penderitaan spiritual dalam kehidupan akhirat diketahui melalui akal murni (unaided reasoni), dan bahwa mereka hanyalah macam-macam kesenangan atau penderitaan yang dapat dialami manusia setelah mati. Tidak ada kesenangan atau penderitaan yang dapat dialami manusia setelah mati. Tidak ada kerancuan logis yang dilibatkan dalam mengemukakan macammacam kesenangan atau pun penderitaan, yang bersifat rohani dan jasmani, seperti juga kebangkitan jasmani yang ditetapkan dalam Kitab Suci. Tuntutan para filosuf, bahwa kesenangan atau penderitaan indrawi, seperti yang dilukiskan dalam Al-Qur'an, tidak lebih dari kiasan-kiasan yang tujuannya adalah untuk kemaslahatan, sangat lemah, dan analogi antara kutipan-kutipan Al-QUr'an yang melukiskannya dan kutipan- 
kutipan nyang merujuk kepada Tuhan dalam istilah-istilah antropomorfik bukanlah sebuah analogi yang masuk akal. Secara logis, tidak mungkin Tuhan dapat diperikan dalam istilah-istilah badani dan sebagian memiliki anggota tubuh atau menempati ruang pahala atau hukuman badani yang telah diperlihatkan dalam bagian umum tentang mukjizat dan hal-hal yang bersifat aneh. Tuhan dapat mengembalikan jiwa pada HAri Kiamat kepada seluruh tubuh yang identik atau sebanding dengan tubuh aslinya. Dengan demikian dapat berbagi kesenangan badani maupun bukan badani. Sebenarnya dengan kemungkinan adanya kenikmatan ganda yang seperti itulah kebahagiaan yang sempurna akan tercapai” (Ibid., h. 355-357).

Ilustrasi tersebut menegaskan bahwa Al-Ghazaly memiliki komitmen dan konsistensi berfikir, meskipun dalam dalam beberapa hal menolak pemikiran filosuf, namun penolakannya ini tidak mungkin dilakukan kecuali dengan menggunakan metode filsafat. Dengan demikian, al-Ghazaly juga adalah seorang filosuf. Akan tetapi komitmennya merujuk Al-Qur'an sebagai kunci jawaban, adalah sebagai kebenaran syariah.

\section{Ijtihad dan Pemikiran Hukum : Pandangan Al-Ghazaly}

Al-Ghazaly merupakan seorang ulama yang tidak setuju bahwa pintu ijtihad telah tertutup. Karena itu, ia memberikan kelonggaran criteria mujtahid, tidak terlalu ketat sebagaimana ulama ushul fiqh yang lain. Dalam al-Mustashfa ia membahas tentang ijtihad dalam Bab al-Quthb al-Rabi' fi Hukm al-Mustatsmir wa huwa al-Mujtahid pada halaman 478-533.

Alasan Al-Ghazaly adalah, bahwa ijtihad merupakan kerja intelektual untuk memformulasikan hukum yang belum atau tidak ditegaskan dalam Al-QUr'an dan al-Sunnah. Lebih dari itu, ijtihad merupakan suatu kebutuhan agar setiap persoalan hukum muncul, dapat diselesaikan. Kebutuhan untuk berijtihad ini telah dirasakan pada masamasa risalah diturunkan kepada Rasulullah saw. demikian juga para sahabat yang kemudian ijtihadnya dikonsultasikan kepada beliau. Banyak riwayat menunjukkan bahwa Rasulullah saw, dalam posisinya sebagai penerima wahyu melakukan ijtihad untuk menghindari kekosongan hukum. Hadits “antum a'lamu bi umur dunyakum.." yang artinya "kalian lebih mengetahui urusan dunia kalian...” (Muslim, juz 2, t.th.:340), nadzar haji seorang perempuan yang belum terlaksana keburu meninggal dunia, dan oleh Rasulullah saw diperintahkan untuk dibayar (Al-Bukhary, juz 2, 1981:217218), tindakan Umar bin al-Khaththab mencium istrinya ketika ia sedang 
berpuasa dan dikiaskan Rasulullah dengan berkumur (Abu Dawud I, 1994:550) adalah beberapa contoh nyata yang menunjukkan bahwa ijtihad memang sangat dibutuhkan. Jika pada masa Rasulullah saw saja ijtihad sudah dilakukan, maka keadaan sekarang, atau setidaknya setelah Rasulullah wafat, ijtihad menjadi sangat-sangat dibutuhkan.

Tentang ijtihad Rasulullah saw ini, para Ulama berbeda pendapat. Syah Waliyullah al-Dahlawy (I, tth: 271) berpendapat, bahwa Rasulullah melakukan ijtihad bukanlah ber-istinbath mengeluarkan hukum dari nash seperti dugaan orang, akan tetapi beliau menerima pengajaran dari Allah tentang maksud syara' dan kaidah-kaidah legislasi (tasyri') untuk memudahkan dan menyelesaikan hukum-hukum yang tidak ditegaskan oleh nash baik Al-Qur'an maupun al-Sunnah. Yang jelas para Ulama sepakat bahwa Rasulullah saw boleh saja berijtihad dalam soal-soal peradilan untuk memutuskan hukum, kemashlahatan keduniaan, perencanan perang, dan lain-lain (al-Syaukany, t.th.: 225, al-Bazdawy, 2: 926). Akan tetapi tentang ijtihad beliau tentang hukum-hukum syara' dan keputusan keagamaan, para ulama berbeda pendapat.

Wahbah al-Zuhaily (1986, 2:1057) mengatakan tiga pendapat. Pertama, kebanyakan ulama ushul mengatakan, secara akal boleh saja Rasulullah saw berijtihad. Ini terjadi dalam wujud perbuatan beliau. Kedua, ulama Hanafiyah berpendapat bahwa beliau diperintah berijtihad ketika terjadi kasus-kasus tertentu setelah menunggu turunnya wahyu, karena khawatir akan tidak adanya status hukum pada persoalan tersebut. Ketiga, mayoritas Ulama Asy'ariyah, teolog, dan kebanyakan ulama Mu'tazilah menyatakan bahwa Rasulullah saw tidak melakukan ijtihad dalam menetapkan hukum syara'.

Persoalannya adalah, siapa dan syarat apa yang harus dipenuhi bagi seseorang yang dibenarkan melakukan ijtihad. Al-Ghazaly mengatakan, ada tiga unsur $(r u k n)$ yang harus dipenuhi oleh seorang mujtahid, pertama, ijtihad, kedua, mujtahid, dan ketiga, sesuatu hukum yang diijtihadi (AlGhazaly, al-Mustashfa, t.th.,: 478). Berikut akan diurai secara singkat:

\section{a. Ijtihad}

Ijtihad, secara bahasa adalah badzl al-majhud wa istifragh al-wus'i fi fill min al-af'al atau mencurahkan segala kemampuan dan kesungguhan 
dalam melakukan suatu pekerjaan dari berbagai pekerjaan. Al-Ghazaly menegaskan, ijtihad hanya pantas dilakukan dalam menyelesaikan persoalan yang berat. Dalam pengertian terminologis, Al-Ghazaly mengacu pada pendapat Ulama lain menyatakan, bahwa kata ijtihad ibatasi pada badzl al-mujtahid wus'ahu fi thalab al-'ilm bi ahkam al-syari'ah artinya mengerahkan kesungguhan dan upaya untuk mencari ilmu (pengetahuan) tenang hukum-hukum syariah.

\section{b. Mujtahid}

Mujtahid, wajib memenuhi dua syarat. Pertama, menguasai (muhith) tentang cara-cara mengetahui syara', yang memungkinkan untuk mendapatkan dugaan dengan penalaran, mendahulukan apa yang wajib didahulukan dan mengakhirkan apa yang wajib diakhirkan. Kedua, seorang mujtahid haruslah adil menjauhi maksiyat yang menjadikan seseorang cacat atau tercela. Hal ini karena orang yang tercela sifat adil ('adalah)-nya tidak dapat diterima fatwanya. Jadi, adil di sini merupan syarat ijtihad atau fatwa, bukan syarat mujtahid atau keabsahan ijtihad.

Al-Ghazaly seorang mujtahid harus memiliki kemampuan memahami syariah secara rinci, dalam wujud: 1). Memahami Kitab Allah. Ia memberi kelonggaran, bahwa seorang mujtahid pada dua hal, yakni: (1). Seorang mujtahid tidak disyaratkan mengetahui seluruh isi kitab, cukup ayat-ayat yang berkaitan dengan hukum, kira-kira 500 ayat; (2). Seorang mujtahid tidak disyaratkan hafal di luar kepala, tetapi mengetahui tempat-tempatnya sekiranya ia mencari ayat-ayat yang dibutuhkan dalam menetapkan hukum. 2). Memahami Al-Sunnah. Seorang mujtahid harus mengetahui hadits-hadits yang berkaitan dengan hukum, kira-kira seribu hadits. Inilah yang merupakan dua kelonggaran Al-Ghazaly yang diberikan kepada seorang mujtahid.

Ini menunjukkan bahwa Al-Ghazaly, lebih mengedepankan misi bahwa Islam harus hadir dalam setiap dibutuhkan, jangan sampai ada kekosongan hukum. Kekosongan hukum akan menyebabkan anomaly dalam masyarakat. 3). Memahami Ijma'. Ijma' adalah kesepakatan para Ulama dalam suatu masalah tentang hukum syara' sesudah Rasulullah saw wafat (Khallaf, 1990:45, Zahrah, tt.:198). Ini karena ijma' merupakan hujjah syar;iyyah yang dibangun atas dasar kesepakatan Ulama (Al-Bashry, 1965: 458). Apabila seorang Ulama berijtihad tidak harus bertentangan 
dengan ijma' yang sudah disepakati para Ulama. Seorang mujtahid juga disarankan memiliki ilmu tentang: (1). Kedudukan dalil dan syaratsyaratnya sehingga dapat menampatkannya sebagai argumentasi burhan) yang jelas. (2). Memahami ilmu bahasa, nahwu, dan ilmu lainnya, agar mudah memahami bahasa Arab. (3). Memahami nasikh dan mansukh dalam ayat Al-Qur'an maupun Al-Sunnah. (4). Memahami periwayatan hadits, sehingga mampu membedakan mana hadits shahih, dla'if, dan yang bisa dijadikan sebagai dalil dalam memformulasikan hukum. AlGhazaly tdak mensyaratkan seorang mujtahid harus memahami ilmu kalam dan cabang-cabang fiqh. Karena, hasil kerja mujtahid adalah fiqh. Karena itu, bisa dilakukan dengan mengikuti para Sahabat (Al-Ghazaly, AlMustashfa, tt.:481).

Al-Ghazaly menambahkan alasan mengapa kelonggaran syarat mujtahid diperlukan? Karena menurutnya, ijtihad adalah suatu kedudukan yang tidak dapat dipisah-pisahkan. Karena itu, boleh saja dikatakan seorang yang alim bisa berijtihad dalam suatu masalah hukum. Misalnya, seseorang memahami metode panalaran analogis, maka dia boleh mengeluarkan fatwa dalam masalah-masalah yang bersifat analogis, meskipun ia tidak menguasai secara lengkap tentang ilmu hadits. Demikian juga seseorang yang memikirkan masalah musyarakah atau musytarakah yakni, pembagian warisan yang ahi warisnya terdiri dari suami $(1 / 2)$, ibu (1/6), dua saudara perempuan seibu (1/3) dan dua saudara laki-laki sekandung (sisa/'ashabah), dan bagian $1 / 3$ untuk dua saudara perempuan seibu kemudian dibagi rata dengan cara musyarakah karena menjadi aneh jika dua saudara laki-laki sekandung tidak mendapat bagian), dia cukup menguasai prinsip-prinsip ilmu faraidl dan artinya. Meskipun dia tidak memahami hadits-hadits yang berkaitan dengan keharaman hal-hal yang memabukkan atau masalah perkawinan tanpa wali.

Bagi Al-Ghazaly, tidaklah menjadi syarat, bahwa seorang mujtahid ketika ditanya tentang 40 masalah, musti dijawab semuanya. Malik misalnya, ditanya 40 masalah, dijawab 36 masalah, dan selebihnya ia mengatakan "saya tidak mengetahuinya". Artinya, persyaratan itu hanya mungkin dilakukan, jika ia memang mengetahui kalau dia mengetahi ( fi ma yadri wa yadri annahu yadri). Dan dapat membedakan di antara hal-hal yang tidak diketahuinya. Jika ia tidak mengetahuinya, maka ia menangguhkan 
(memauqufkan) hal-hal yang tidak diketahui dan memfatwakan hal-hal yang diketahuinya (AL-Ghazaly, t.t: 481).

Persyaratan mujtahid bagi Ulama lain, memang lebih berat, yakni delapan syarat: (1). Memahami bahasa Arab. Ini merupakan suatu keharusan (condition sine quanon). (2). Memahami ilmu Al-Qur'an. Syarat ini ditetapkan oleh al-Syafi'i, alasannya Al-Qur'an adalah tiangnya syari'ah, tali Allah yang diulur hingga hari kiamat dan sumber syariah. Al-Syafíi juga menyarankan, sebaiknya seorang mujtahid hendaknya hafal Al-Qur'an. (3). Memahami al-Sunnah. Syarat ini termasuk syarat yang disepakati Ulama. Bagaimana seseorang dapat melakukan ijtihad manakala ia tidak memahami al-Sunnah. (4). Memahami persoalan ijma', seperti prinsip hukum fardlu, seperti bilangan rakaat shalat, dan lain-lain, dengan dasar hukum yang secara mutawatir telah ada periwayatan. (5). Memahami qiyas sebagai metode istinbath hukum. Al-Asnawy dalam al-Minhaj (tt.: 310) mengatakan "suatu yang tidak boleh tidak adalah, seorang mujtahid memahami qiyas dan syarat-syaratnya, karena qiyas merupakan kaidah ijtihad dan dapat mencapai ilmu-ilmu yang tidak terbatas. Al-Syafi'i bahkan menerapkan hukum yang ada pada hukum asal pada hukum cabang yang belum ada ketetapan hukumnya, karena ada persamaan illat hukum (alBashry, II, 1965:697). (6). Memahami tujuan hukum (maqashid al-syari'ah). Tujuan syariah adalah merealisasikan kemashlahatan bagi manusia. Karena dengan demikian, seorang mujtahid mampu membedakan mana yang mashlahat dan madharat bagi manusia. (7). Mujtahid harus memiliki pemahaman yang sehat dan perkiraan yang baik. Al-Asnawy (Ibid,) mengatakan, seorang mujtahid disyaratkan mengetahui syarat-syarat had, burhan, bagaimana cara menyusun premis dan membuat konklusi untuk menghindari kekeliruan cara berfikir. Dengan kata lain, seorang mujtahid perlu memahami ilmu manthiq. Agar mampu berfikir lurus dan logis. (8). Niat dan akidahnya benar. Niat yang ikhlas menjadikan hatinya tersinari oleh cahaya Allah, yang ketika memformulasikan hukum melahirkan rasa cinta yang tulus kepada agama untuk mendapatkan kebenaran dan keadilan bagi manusia.

Abu Zahrah (Tarikh... tt.: 121) mengklasifikasikan mujtahid pada (1). Mujtahid Mustaqil, yakni mujtahid yang mengeluarkan hukum dari sumbernya, dengan merumuskan metode ijtihad sendiri. Nama yang 
disebut adalah Sa'id bin al-Musayyab, Ibrahim al-Nakha'i, Ja'far al-Shadiq, Abu Hanifah, Malik, Syafi'i, Ahmad bin Hanbal, dan al-Auza'i. (2), Mujtahid Muntasib, yakni mujtahid yang dalam melakukan ijtihad mengacu pada metode yang telah ditetapkan oleh para Ulama sebelumnya, akan tetapi mereka berbeda pendapat dalam soal cabang ( $\left.f u r u^{\prime}\right)$. Ulama yang dimasukkan kelompok ini di antaranya : Khalid bin Yusuf dalam madzhab Hanafy, Hasan bin Ziyad al-Lu'lui, al-Muzany dalam madzhab Syafi'i, dan 'Abd al-Rahman bin al-Qasim al-Maliky. (3). Mujtahid fi al-Madzhab yaitu mujtahid yang mengikuti imam madzhabnya baik dalam soal ushul maupun furu'nya. Mereka juga tidak berbeda pendapat dengan gurunya tetapi lebih banyak menyelesaikan persoalan yang beum dibahas oleh gurunya. (4). Mujtahid Murajjih, Mujtahid Murajjih, yaitu mujtahid yang tidak melakukan istinbath hukum, akan tetapi membatasi pada mentarjih pendapat-pendapat yang diriwayatkan melalui seleksi mana yang didasari dalil yang lebih kuat. (5). Mustadillin, yaitu ulama yang menggunakan dalil terhadap pendapat para ulama dan menjelaskan mana dalil yang dipedomaninya tanpa mentarjih mana pendapat yang mereka anggap lebih kuat. (6). Muqallid, yaitu orang yang mengikuti ulama. Ada dua, pertama, thabaqat al-huffadh, yakni tidak termasuk peringkat mujtahid, mereka hafal kebanyakan hukum yang telah dirumuskan oleh para Ulama madzhab, dan kedua, muqallid, yaitu para ulama yang memahami beberapa kitab tentang tarjih, namun dia sendiri tidak mampu melakukan tarjih dan tidak memiliki ilmu tentang tarjih tersebut.

Wahbah al-Zuhaily (2: 1079-1081) mengklasifikasikan mujtahid pada lima tingkatan, yakni: (1). Mujtahid Mustaqill; (2). Mujtahid Muthlaq Ghairu Mustaqill, sering disebut juga dengan Mujtahid Muthlaq Muntasib, seperti Abu Yusuf, Muhammad al-Syaibany, al-Za'farany, alMuzany dari Madzhab Syafi'iyah. (3). Mujtahid Muqayyad atau Mujtahid Mukharrij, yakni mujtahid yang terikat pada madzhab imamnya, seperti: Hasan bin Ziyad, al-Karkhy, al-Thahawy dari Madzhab Hanafiyah. (4). Mujtahid Tarjih, yaitu mujtahid yang mampu melakukan tarjih pendapat para imam madzhab; (5). Mujtahid Fatwa, yaitu mujtahid yang lebih banyak memelihara madzhab, menukil dan memahaminya dalam soalsoal yang jelas dan musykil, tetapi lemah dalam menetapkan dalil dan melakukan qiyas. 


\section{c. Masalah-masalah yang Diijtihadi}

Al-Ghazaly menegaskan bahwa hukum yang boleh diijtihadi adalah semua hukum syara' yang tidak diatur oleh dalil qath'iy (al-Mustashfa, tt. : 482). Dalil Qath'iy adalah dalil yang tidak memungkinkan untuk dita'wili, seperti ketentuan tentnag wajibnya shalat, wajibnya zakat, puasa, haji, dan ketentuan hukum yang sudah baku dari agama (al-ma'lum min al-din bi al-dlarurah). Dengan tegas al-Ghazaly mengatakan, berdosa orang yang melakukan ijtihad dalam hal-hal yang sudah ada ketentuan bakunya. Ini karena terkait dengan persoalan kebenaran, karena belum ada dalilnya. Bagi yang sudah ada dalilnya secara qath'iy, maka jika ijtihadnya keliru, berarti berdosa, dan tidak mendapatkan pahala, sebagaimana hadits Rasulullah saw. Yang termasuk qath'iy menurut Al-Ghazaly ada tiga: pertama, bersifat teologis, yang benar hanya satu. Selain itu adalah salah, dan berarti dosa. Termasuk dalam hal ini, tentang barunya alam, diutusnya Rasul, pembenaran mu'jizat, dan lain-lain. Orang yang salah dalam hal ini mengakibatkan kafir. Kedua, ushuliyah (metodologis) seperti ijma' adalah hujjah, meskipun ada perbedaan pendapat dalam hal ini. Ketiga, fiqhiyah (fiqh) seperti wajibnya shalat lima waktu, zakat dan puasa, diharamkannya zina, minum khamr, dan hal-hal lain yang sudah pasti dalam agama, kebenarannya hanya satu. Orang yang berbeda dengan ketentuan ini berdosa, dan yang mengingkarinya dapat dikatagorikan kafir.

Al-Zuhaily (2:1053) mengatakan bahwa hal-gal yang boleh diijtihadi adalah hukum-hukum yang ada ketentuan nashnya akan tetapi termasuk kategori dhanny al-tsubut dan dhanny al-dilalah atau dhanny salah satunya serta hukum-hukum yang tidak ada nash dan ijma'nya.

Dalam dalil yang dhanny al-tsubut maka wilayah ijtihadnya adalah membahas sanad dan cara periwayatannya kepada kita, derajat perawinya dari segi dlabith atau tidaknya, 'adalah atau ke-tsiqah-annya. Apabila nash tersebut termasuk kategori dhanny al-dilalah maka wilayah ijtihadnya adalah meneliti makna yang dimaksud nash tersebut serta kekuatan dalalahnya atas makna tersebut. Karena ada kalanya, dalil tersebut menunjukkan makna umum atau mutlak, dan kadang juga dengan redaksi perintah atau larangan.

Apabila kasus-kasus hukum tidak ada nash aau ijma' yang telah menetapkan hukumnya, wilayah ijtihadnya adalah menggunakan 
penentuan hukumnya dengan dalil-dalil aqly seperti: qiyas, istihsan, mashlahat mursalah, 'urf, istishhab, atau dalil lain yang menjadi perbedaan pendapat para Ulama. Dengan demikian dpat ditegaskan bahwa wilayah ijtihad adalah hukum yang tidak ada ketentuan nashnya dan atau ada nasshnya akan tetapi tidak bersifat qath'iy (Ibn al-Qayyim, 2: 260, alSyathiby, 4: 155, al-Syaukany, tt.:222).

Ilustrasi di atas menegaskan bahwa sesungguhnya ijtihad sebagai kerja inteletkual Ulama yang memiliki kompetensi secara serius, merupakan suatu kebutuhan yang tidak boleh tidak harus tetap dilakukan. Al-Zuhaily (2:1087) menegaskan, bahwa ijtihad merupakan lehidupan syariah, maka syariah tidak akan langgeng selama fiqh dan ijtihad di dalamnya tidak hidup dan berjalan baik dalam bentuk perbuatan maupun gerakan. Al-Ghazaly lebih tegas lagi, menyebutkan bahwa al-ijtihad rukn 'adhim fi al-syariah artinya ijtihad merupakan unsur besar atau penting dalam syariah (Al-Ghazaly, al-Mankhul tt:462). Karena akibat dari pertumbuhan dna perkembangan kehiduipan serta konsekuensi tersebarnya syariah menuntut ijtihad ini tetap hidup. Bagi al-Zuhaily, sekarang pun ijtihad tetap diperlukan. Lebih-lebih ketika transaksi modern, kejadian-kejadian yang rumit, perkembangan sains dan teknologi, terus menerus terjadi. Membiarkan persoalan bermunculan dengan duduk manis dan bermalasmalas serta rela menerima apa yang telah digariskan kitab-kitab fiqh, adalah suatu tindakan yang tidak diridhai oleh Allah dan Rasul-Nya. Dalam redaksi yang agak panjang, al-Zuhaily menegaskan:

"Ijtihad adalah sesuatu yang memungkinkan di setiap keadaan, tidak ada kesulitan di dalamnya, dengan syarat mengubur prasangka-prasangka dan takhayul, dan menghapus karat yang membelenggu akal dan hati kita dari endapan kotoran-kotoran yang telah lalu dan bahaya (bayangan) ketidakmampuan, prasangka-prasangka dosa, dengan tidak adanya kemungkinan untuk mencapai apa yang telah dicapai generasi terdahulu. Seakan-akan hal itu suatu kemustahilan".

Karena itu, munculnya gerakan pintu ijtihad tertutup, adalah merupakan persoalan politik ( $\min$ bab al-siyasah al-syar'iyyah) untuk menolong orang tertentu, sesuatu yang temporer, atau karena bencana ijtihadi akibat dari tuduhan tidak adanya kemampuan ijtihad. Alternatifnya adalah, kembali kepada prinsip hukum, yaitu membuka pntu ijtihad atau fath bab al-ijtihad. Alasnnya, tidak ada dasar hukum yang menjelaskan 
tentang penutupan pintu ijtihad, kecuali tuduhan tidak bermakna dan argumentasi rendahan yang lebih hina dari sarang laba-laba. Karena tidak ada sandaran dalil syar'iy maupun 'aqly kecuali hanya mewarisi (Albany, tt: 62).

\section{Teori Kebenaran dalam Pandangan Ulama}

Al-Ghazaly menegaskan, mengacu kepada hadits Rasulullah saw yang menegaskan: "Idza hakama al-hakim wa ijtahada fa ashaba fa lahu ajran, wa idza hakama wa ijtahada fa akhtha'a fa lahu ajran artinya "ketika hakim menetapkan hukum, berijtihad, dan ijtihadnya benar, maka baginya dua pahala, dan jika hakim berijtihad, dan salah ijtihadnya, maka baginya satu pahala" (Muslim, 2:62) bahwa tugas ijtihad merupakan bagian yang melekat atau menyatu dengan diri seorang hakim (qadli) atau pemberi keputusan hukum lainnya. Termasuk di dala

Ini diperkuat lagi dengan hadits yang menjelaskan, bahwa ketika Rasulullah saw mengutus sahabat Mu'adz bin Jabal menjadi qadli di Yaman, beliau bertanya: "Dengan apa kamu akan memutuskan hukum?" Mu’adz menjawab: “Dengan Kitab Allah”. Bagaimana jika tidak kamu dapati (hukum) di dalamnya?" Tanya Rasul. Mu’adz menjawab: "Dengan sunnah Rasulullah". Rasulullah saw bertanya lagi : "Jika kamu tidak mendapati (hukum) di dalamnya?” Mu’adz menjawab: "AKu berijtihad dan tidak lalai”. Mendengar jawaban Mu’adz, Rasulullah saw memujinya seraya membenarkan langkah ijtihad yang dilakukan Mu'adz.

Beban dan tanggung jawab untuk melakukan ijtihad tidak saja menjadi tugas melekat bagi seorang hakim, akan tetapi juga bagi para Ulama, apakah karena diminta atau tidak. Ulama dituntut lebih responsif merespon dan mencarikan solusi bagi kekosongan hukum agar tidak terjadi anomaly hukum dalam masyarakat.

Pertanyaan yang paling mendasar adalah, apakah setiap ijtihad yang dilakukan oleh seorang mujtahid atau ulama itu benar? Atau mungkin salah? Al-Ghazaaly sebelum sampai pada kesimpulan tentang jawaban apakah setiap ijtihad yang dilakukan mujtahid atau ulama itu benar atau salah, mengemukakan perbedaan pendapat di kalangan ulama. Mengutip dari Al-Syafi'i, Abu Hanifah, dan sebagian besar Ulama, Al-Ghazaly mengatakan bahwa setiap mujtahid (yang melakukan ijtihad) dalam 
persoalan yang termasuk kategori dhanniyat adalah benar (Al-Mustashfa, t.t. : 492). Sementara ulama lain menegaskan bahwa ijtihad yang benar adalah satu. Berarti yang lain salah. Akan tetapi dalam kitab Al-Mankhul (tt. : 453) Al-Ghazaly menyebutkan bahwa Al-Syafi'i, Abu Ishaq, dan sekelompok Fuqaha' menyatakan bahwa hasil ijtihad yang benar adalah satu dan mendapat dua pahala, tetapi yang salah menerima satu pahala.

Yang menjadi pemicu perbedaan pendapat adalah apakah dalam setiap kejadian yang tidak ada ketentuan hukumnya dalam nash, harus dicari oleh mujtahid? Kelompok yang menganut teori "Pembenaran" (Mushawwibah) berpendapat bahwa dalam kasus-kasus hukum yang tidak ada ketentuan nashnya, maka dicari berdasarkan dugaan (al-dhann). Penetapan hukumnya didasarkan dugaan, dan hukum Alah bagi setiap mujtahid adalah apa yang dominan dalam dugaan tersebut (ghalabah aldhann). Ini pendapat yang dipilih.

Sama-sama menganut teori pembenaran, ada yang mengatakan, bahwa di dalamnya ada ketentuan hukum yang didapatkan dengan pencarian, karena sudah pasti dalam pencarian itu seorang mujtahid tidak dipaksa harus benar. Karena itu hasil ijtihadnya adalah benar. Maka ketika ternyata hukum yang ditentukan itu salah, karena memang tidak diperintah harus benar, maka artinya ia telah memenuhi sesuatu yang dibebankan kepadanya, maka benarlah apa yang dilakukannya.

Ulama yang mengatakan bahwa ijtihad yang benar hanya satu, dan yang lain salah, sepakat bahwa pada prinsipnya dalam setiap kasus hukum, ada ketentuan hukumnya dari Allah. Masalahnya adalah, bahwa mereka berbeda pendapat apakah ada dalil yang jelas atau tidak? Kontroversi ini makin melebar sehubungan dengan penyelesaian dengan cara qiyas (analogi). Al-Ghazaly mengutip dari Bisyr al-Marisy yang menyatakan bahwa apabila dalam kasus tersebut terdapat dalil qath'iy, maka berdosalah mujtahid yang keliru, seperti halnya dalam masalah-masalah yang qath'iy lainnya. Akan tetapi jika tidak ada dalil qath'iy yang mengaturnya, maka dipertanayakan lagi apakah mujtahid diperintah harus benar secara pasti? Sebagian mengatakan bahwa seorang mujtahid tidak mesti menjangkau kebenaran, karena samar dan rumitnya persoalan. Karena itu selain ada halangan ( $\left.m a^{\prime} d z u r\right)$ juga tetap dijanjikan pahala ( $\left.m a^{\prime} j u r\right)$. Sementara yang 
lain ada yang mengatakan, jika ijtihadnya salah tidak diberi pahala, tetapi bagian dosanya ringan.

Al-Ghazaly sendiri menegaskan pendapatnya, dengan reasoning dan argumentasi bahwa untuk memastikan ini dan menyalahkan orang yang berbeda pendapt, bahwa setiap mujtahid dalam soal-soal yang dhanny adalah benar, karena tidak ada ketentuan hukum dari Allah secara pasti. Kelihatannya dalam hal ini, Al-Ghazaly melihatnya secara kasuistik dari kemampuan dan kondisi mujtahid yang bersangkutan. Pertama, terhadap masalah yang ada nashnya, apabila mujtahidnya salah, jika nash ada dan dapat dijangkau seandainya mujtahid tersebut bersungguh-sungguh, tetapi tidak dilakukannya (taqshir, maka dia salah dan berdosa karena dia tidak bersungguh-sungguh. Akan tetapi kalau dia telah berusaha seungguh-sungguh karena bebera[a alas an karena jauh atau terlambat penyampaiannya, maka dikategorikan keliru secara majazy. Sebab sekiranya ia mengetahui nash tersebut, maka dia pada hakikatnya tidak akan keliru. AL-Ghazaly mencontohkan, "sekiranya Rasulullah saw shalat dengan menghadap Baitul MAqdis setelah Allah memerintah Jibril untuk menurunkan dan memberitakan kepada nabi Muhammad saw supaya mengalihkan qiblatnya, maka Nabi tidak keliru. Karena perintah menghadap Ka'bah sudah diturunkan tetapi belm disampaikan kepada Nabi. Demikian juga kalau perintah telah turun dan diberikan, sementara penduduk Masjid Quba' shalat menghadap Baitul Maqdis dan sesudah itu Nabi belum mengabarkan kepada mereka, maka mereka tidak salah. Karena ketentuan hukum sudah ada tetapi tidak sampai kepada mereka (Al-Ghazaly, Al-Mustashfa, tt. : 493).

Lebih jauh Al-Ghazaly menegaskan, sekiranya ada dalil qath'iy atau dalil dhanny tentang suatu kasus, dan seorang mujtahid tidak memperhatikannya sementara ia memiliki kemampuan untuk itu, maka dia termasuk pendosa yang maksiyat. Karena itu, dosa adalah wajib baginya. Kesalahannya itu merupakan keharusan, apakah itu masalah fiqhiyah, ushuliyah, atau teologis. Akan tetapi jika dalammasalah tersebut tidak ada dalil qath'iy maka, kata Al-Ghaaaly, sama halnya dengan membebani kebenaran dalam ijtihad tanpa ada dalil qath'iy, adalah pembebanan yang tidak mungkin (taklif muhal). Maka jika tidak ada beban, im 
Abu al-Ma'aly al-Juwainy $(419-478 \mathrm{H})$ dalam kitab Al-Burhan $\mathrm{fi}$ Ushul al-Fiqh (2: 861) menjelaskan perbedan pendapat para Ulama dengan mempertimbangkan pada wilayah ijtihad. Sementara itu, Abu al-Hasan alBashry yang diikuti oleh ulama terdahulu yang juga mengambil dari AlSyafi'i, berpendapat bahwa para mujtahid benar dalam ijtihadnya. Abu Ishaq menjelaskan bahwa pendapat yang membenarkan para mujtahid, pertama adalah Safsathah dan akhirnya Zandaqah. Dan inilah pendapat yang popular dari madzhab Syafi'i.

Dari kelompok yang menyatakan bahwa mujtahid benar terbagi menjadi dua: pertama, mereka yang bermaksud bahwa kejadian-kejadian yang tidak ada nash dan ijma' di dalamnya, tidak ada ketentuan hukum yang jelas. Akan tetapi bagi mereka yang berfikir bahwa di situ ada beban mencari dan berijtihad. Jika dugaannya dominan, maka hukum Allah mengikuti dugaannya itu, dan wajib baginya menetapkannya. Sementara kelompok (Syiah) Ghulat menyatakan bahwa mereka tidak dituntut untuk berijtihad, tidak ada ijtihad, mereka mengerjakan dengan cara memilih mana yang dikehendaki. Pendapat ini, menurut hemat penulis, tidak jelas juga. Karena sesungguhnya untuk melakukan pemilihan sesungguhnya adalah sebuah usaha juga.

Al-Juwainy menambahkan bahwa orang-orang yang benar ijtihadnya mendapat dua pahala, dan yang salah merupakan halangan (ma'dzur). Ghulat mengatakan, bahwa orang yang salah berdosa, disiksa dan dibebani. Al-Juwainy berkesimpulan, bahwa orang-orang yang menyatakan bahwa yang benar hanya satu, mustahil bahwa dalam satu hal ada ketentuan halal dan haram sekaligus. Karena ini bertentangan dan saling meniadakan (menafikan) atau mutanaqidlan mutanafiyan. Ketika dikatakan kepada mereka "Bangkai haram bagi yang tidak terpaksa, dan halal bagi yang terpaksa", mereka menjawab "terpautnya hukum halal dan haram adalah merupakan hak dua orang" "Orang yang mewajibkan dirinya mengikuti dugaannya, ia meyakini bahwa apayang diduga adalah benar. Maka keduanya juga dugaan dari dua orang" (Ibid., 862).

Tidak ada keraguan bahwa setiap mujtahid melakukan sesuai dengan hasil ijtihadnya. Ini kesepakatan dan tidak ada keraguan. Bagi mujtahid yang ijtihadnya menghasilkan yang halal, maka ia wajib mengamalkannya karena ijtihadnya itu. Dan mujtahid yang sampai pada 
ketetapan haram, maka wajib baginya menjalankan ketetapan ijtihadnya itu. Dan kewajiban mengamalkan ketetapan dua ijtihad adalah termasuk perintah dan kewajiban (agama) yang diberikan oleh Allah (Ibid., 83).

Apabila dicermati secara mendalam, sesungguhnya pendapat kedua tokoh tersebut, Al-Juwainy dan Al-Ghazaly, hamper sama. Artinya, ijtihad yang lahannya adalah dalil dhanny maka sepanjang dilakukan oleh orang yang memiliki cukup syarat (kompetensi) adalah benar. Karena ijtihad dibangun atas dasar dugaan yang kuat (ghalabah al-dhann). Setiap mujtahid menduga apa yang diusahakannya adalah benar, dank arena itu ia wajib mengamalkannya. Maka berarti apa yang diijtihadkannya adalah benar.

Adapun soal perbedaan pendapat di antara Ulama, Al-Ghazaly menyatakan ada tiga hal yang perlu diketahui. Pertama, perbedaan hukum timbul karena perbedaan seseorang dalam ilmu, kebodohan, dan dugaan. Seperti perbedaan karena bepergian atau muqim, hadil dan suci, merdeka dan budak, dalam keadaan teraksa atau leluasa. Kedua, umat sepakat bahwa bagi orang-orang yang berbeda pendapat wajib melakukan ijtihad untuk menentukan hukum sesuai dengan ijtihadnya berbeda dengan yang lainnya. Perintah untuk mengikuti orang yang berbeda pendapat sama halnya perintah untuk berbedda pendapat. Pertanyaan semacam ini, sahsah saja bagi yang mengingkari prinsip ijtihad. Ketiga, ini jawaban orang yang mengingkari prinsip ijtihad, sekiranya yang dimaksud dari apa yang mereka kehendki, boleh saja mujtahid dalam soal kiblat menghadap pada arah hang berbeda, sementara kiblat bagi Allah adalah satu. Itu yang menurut Al-Ghazaly, yang disebut dengan tahqiq manath al-hukm.

Al-Ghazaly menetapkan ijtihad yang salah karena empat hal. Pertama, apabila ijtihad itu dilakukan oleh orang yang tidak menguasai (ahli) dan tidak kompeten. Kedua, tidak sempurna (pandangan) dan penalaran mujtahid. Ketiga, keliru dalam meletakkan ijtihad yang bukan pada tempatnya, yakni pada dalil qath'iy. Keempat, mujtahid dalam ijtihadnya berbeda dengan dalil qath'iy. Seorang mujtahid tidak akan salah (yantafi al-khatha') apabila dilakukan oleh orang yang memenuhi criteria atau kualifikasi mujtahid, sempurna dirinya, dan menempatkan ijtihad pada posisinya, dan tidak menentang dalil-dalil qath'iy. Kalau pun mereka keliru, karena ia bersandar kepada apa yang dicari, bkan pada kewajibannya 
menghadap kiblat. Dan inilah yang diharampakn dan dilakukan oleh seorang mujtahid (Al-Mustashfa, 504).

Seolah-olah Al-Ghazaly memberikan kelonggaran kualifikasi dan persyaratan kompetensi seorang mujtahid, tetapi sesungguhnya ruang lingkup pembatasan ranah ijtihad pada wilayah hukum yang dalil-dalilnya dhanny sebenarnya sudah merupakan bentuk kehati-hatian yang luar biasa ekstra. Dengan demikian tidak ada kekhawatiran, seorang mujtahid akan terjebak ke dalam hasil ijtihad yang menabrak dalil-dalil qath'iy.

\section{Simpulan}

Dari uraian dan analisis di atas dapat ditegaskan bahwa penelitian ini menemukan hal-hal sebagai berikut. Pertama, teori kebenaran menurut AlGhazaly, adalah sesuatu yang diyakini kebenarannya secara pasti. Kepastian ini mengalami beberapa tahapan yang diawali dari kebenaran indrawi, akan tetapi kebenaran indrawi ini tidak meyakinkan, maka kebenaran yang meyakinkan adalah kebenaran melalui akal. Kebenaran melalui akal, ternyata juga tidak meyakinkan, lebih-lebih ketika berhadapan dengan ketentuan syara.' Karena itu, kebenarana bagi orang awam, berbeda dengan kebenaran menurut orang tertentu (khawash). Jika orang awam dibatasi untuk mengikuti saja, karena membebani mereka di luar kemampuannya, merupakan sesuatu yang mustahil. Untuk mencari kebenaran harus dilalui dengan berfikir, meneliti, dan jika perlu meninggalkan pengertianpengertian lahiriyah untuk mencari kebenaran yang hakiki atau dalam hal tertentu bersifat batiniyah. Dalam hal ini, kesepakatan memiliki arti penting bagi upaya membangun sebuah kebenaran. Pemikiran Al-Ghazaly semacam ini dilatarbelakangi oleh pengalaman spiritual dan pemikirannya dari ahli fiqh (juris), teolog, filosuf, hingga menjadi sufi. Karena itu, meletakkan konsep kebenaran menjadi bersifat tentative dan spekulatif sifatanya, lebih-lebih bagi orang lain. Akan tetapi bagi dirinya sendiri, proses pengembaraan intelektual dan batini, yang sesungguhnya dapat lebih tepat dan proporsional menempatkan kebenaran yang diyakininya secara pasti.

Kedua, dalam perspektif pemikiran hukum Islam, Al-Ghazaly mengatakan bahwa mujtahid yang berijtihad adalah benar. Namun untuk menetapkan kebenaran ini, criteria dan persyaratan mujtahid perlu dipenuhi 
meskipun sedikit lebih longgar disbanding dengan ulama yang lain. Seorang mujtahid tidak harus hafal seluruh ayat Al-Qur'an dan alOSunnah, akan tetaopi cukup memahami ayat-ayat hukum kira-kira 500 ayat, haditshadits hukum dari kitab-kitab hadits, seperti Sunan Abi Dawud, Sunan al-Nasai, yang memang lebih focus pada hadits-hadits hukum. Meskipun terkesan longgar dalam persyaratan, Al-Ghazaly membatasi wilayah ijtihad (majal al-ijtihad) yang tepat, hanyalah pada wilayah yang di luar ketentuan ayat-ayat yang qath'iy. Yang merupakan ketentuan agama yang sudah diketahui secara pasti (al-ma'lum min al-din bi al-dlarurah). Karena itu seorang mujtahid tidak perlu khawatir akan terjebak dalam kekeliruan. Beban ijtihad (taklif al-ijtihad) kepada seseorang dilakukan dalam wilayah yang memang berada dalam jangkauannya, yakni pada wilayah dugaan yang kuat (ghalabah al-dhann). Ketika seorang mujtahid meyakini berdassarkan dugaan kuat tadi, maka sesungguhnya ia telah melakukannya sesuai dengan perintah Allah. Karena Allah tidak mungkin membebani sesuatu kepada hamba-hamba-Nya daalam hal yang berada di luar kemamuan mereka. 


\section{BIBLIOGRAFI}

Abu Dawud, Sunan Abi Dawud, juz 1-2, Beirut: Dar al-Fikr, 1414 H/1994 M.

Abu Zahrah, Muhammad, Muhadlarah fi Tarikh al-Madzahib al-Fiqhiyah, Mesir: Mathba'ah al-Madany, tt.

Al-Bashry, Abu al-Husain, Kitab al-Mu'tamad fi Ushul al-Fiqh, juz 1-2, Damsyiq: al-Ma'had al-'Ilm al-Faransa li al-Dirasat al-Arabiyah, 1384 H/1964 M.

Al-Bazdawy, Ushul al-Bazdawy, Karachi, tt.

Al-Bukhary, Shahih al-Bukhary, juz 2, Beirut: Dar al-Fikr, 1981.

Al-Dahlawy, Syah Waliyullah, Hujjah Allah al-Balaghah, juz 1, tt.: Dar alKutub al-Haditsah, tt.

Fakhry, Madjid, Sejarah Filsafat Islam, (Terj. Mulyadi Kertanegara), Jakarta: Pustaka Jaya, cet. 1, 1986.

Al-Ghazaly, Abu Hamid, Al-Mustashfa min 'Ilm al-Ushul, tt. : Syirkah alThiba'ah al-Fanniyah al-Muttahidah, t.th.

, Al-Mankhul min Ta'liqat al-Ushul, Damsyiq: Dar al-Fikr, $` 400 \mathrm{H} / ` 980 \mathrm{M}$. , Al-Munqidz min al-Dlalal, Beirut: al-Maktabah al-Sya'niyah, t.th. , Tahafut al-Falasifah, Mesir: Dar al-Ma'arif, 1972.

Hitti, Philip K, History of The Arabs, New York: The Macmillan Press, 1974.

Al-Juwainy, Abu al-Ma'aly, Al-Burhan fi Ushul al-Fiqh, juz 1-2, Mesir: Dar al-Wafa', $1412 \mathrm{H} / 1992 \mathrm{M}$.

Khallaf, 'Abd al-Wahhab, 'Ilm Ushul al-Fiqh, al-Qahirah: Maktabah alDa'wah al-Islamiyah, 1410 H/1990 M.

Madjid, Noercholish, Khazanah Intelektual Islam, Jakarta: Bulan Bingtang, 1984.

Al-Maraghy, Ahmad Musthafa, Al-Fath al-Mubin $f i$ Thabaqat al-Ushuliyyin, Mesir: Muhammad Amin Damaj, 1394 H/1974 M. 
Mastuhu, Ridwan, M, Deden (eds), Tradisi BAru Penelitian Agama Islam, Bandung: Nuansa, 1998.

Montgomery, Watt, W, Pemikiran Teologi dan Filsafat Islam, (Terj,. Umar Basalim), Jakarta: P3M, 1987.

Muslim, Shahih Muslim, juz 2, Jakarta: Dar Ihya' al-Kutub al-Arabiyah, tt.

Nasution, Harun, Falsafat dan Mistisisme dalam islam, Jakarta: Bulan Bintang, 1989.

Al-Syafi'i, Muhammad bin Idris, Al-Risalah, Beirut : Dar al-Fikr, t.t.

Al-Syathiby, Abu Ishaq Ibrahim bin Musa, Al-Muwafaqat fi Ushul al-Ahkam, juz 1-2, Beirut, tt.

Al-Syaukani, Muhammad bin 'Ali, Irsyad al-Fukhul, Beirut: Dar al-Fikr, tt.

Tiwana, Muhammad Musa, Al-Ijtihad wa Mada Hajatina fi Hadza al-'Ashr, Mesir: Dar al-Kutub al-Haditsah, tt.

Al-Zuhaily, Wahbah, Al-Wasith fi Ushul al-Fiqh, Damsyiq: Mathba'ah Dar al-Kitab, 1397 H/1977 M. , Ushul al-Fiqh, juz 1-2, Beirut : Dar al-Fikr, 1406 H/1986 M. 
